\title{
PEMBANGUNAN APLIKASI INFORMASI LOKASI VENUE PEKAN OLAHRAGA NASIONAL (PON) XIX DI JAWA BARAT 2016 BERBASIS ANDROID
}

\author{
Fitri Sya'bandyah ${ }^{1)}$, Wildan Badryan ${ }^{2)}$ \\ Program Studi Teknik Informatika ${ }^{12)}$ \\ Universitas Sangga Buana YPKP Bandung ${ }^{122}$ \\ Fitri.syabandyah@usbypkpk.ac.id ${ }^{1)}$, wildan.badryan@gmail.com ${ }^{2)}$
}

\begin{abstract}
Abstrak
Pekan Olahraga Nasional (PON) adalah pesta olahraga nasional di Indonesia yang di adakaan setiap empat tahun sekali dan di ikuti seluruh provinsi di indonesia. Semakin dekatnya waktu pelaksanaan Pekan Olahraga Nasional di Jawa Barat membuat kebutuhan informasi akan venue dari setiap cabang olahraga yang di pertandingkan semakin meningkat.

Salah satu solusi untuk mengatasi masalah tersebut adalah dengan memanfaatkan aplikasi pencarian lokasi, salah satunya dengan Location Based Service( LBS). Layanan berbasis lokasi yang menyediakan informasi mengenai suatu tempat. LBS mendapatkan posisi geografis dengan menggunakan bantuan GPS( Global Possitioning System). GPS ini merupakan sistem menggunakan titik kordinat posisi dan navigasi secara global dengan menggunakan satelit. Tujuan penelitian ini untuk menghasilkan aplikasi client server dimana website sebagai server dan android sebagai client yang menampikan data lokasi venue Pekan Olahraga Nasional (PON) XIX di jawa barat 2016.

Hasil yang di capai yakni website sebagai server yang mengelola data venue yang dapat membantu pengguan smartphone dengan sistem operasi android untuk mencari lokasi venue pertandingan
\end{abstract}

Kata Kunci : Pekan Olahraga Nasional (PON), LBS, GPS, Android.

\section{PENDAHULUAN}

\subsection{Latar Belakang}

Kemajuan teknologi merupakan hal yang patut untuk kita syukuri, sebab dengan hadirnya teknologi berbagai pemenuhan kebutuhan hidup manusia menjadi lebih mudah. Pada dasarnya teknologi menjadi bukti perkembangan kemampuan manusia untuk menggunakan nalar dan pikirannya dalam mengelola alam dan potensi diri manusia itu sendiri.

Hadirnya teknologi berbasis clientserver dengan website sebagai server dan mobile sebagai client yang semakin pesat dan maju tidak dapat dihindari, juga berdampak positif yang memudahkan setiap orang saling bertukar informasi, sehingga jarak tidak lagi menjadi sebuah penghalang. Saat ini media mobile perkembangannya sangat pesat dari sekedar alat untuk berkomunikasi suara, teks maupun visual menjadi sebuah perangkat cerdas dengan berbagai fungsi seperti mengolah foto atau gambar, mengakses video, dan koneksi internet.

Salah satu media mobile yang sedang banyak digunakan saat ini adalah ponsel cerdas berbasis Android. Android adalah sistem operasi berbasis linux untuk telepon seluler seperti telepon pintar dan tablet, yang dikembangkan oleh perusahaan google pada tahun 2005. Keunggulan Android menjadikannya populer di kalangan masyarakat bahkan telah merambah ke dunia olahraga, hal tersebut karena Android memiliki fitur canggih yang dapat mempermudah olahragawan untuk memantau kebugaran, melacak jarak bahkan menentukan rute tempuh.

Pekan Olahraga Nasional (PON) adalah pesta olahraga nasional di Indonesia yang diadakan setiap empat tahun sekali dan diikuti seluruh provinsi di Indonesia. Seiring 
terpilihnya provinsi Jawa Barat menjadi tuan rumah dan sekaligus pelaksana sebuah perhelatan ragam olahraga setingkat Pekan Olahraga Nasional (PON) XIX. Dengan 61 venue dari setiap cabang olahraga yang dipertandingkan di 15 Kabupaten/Kota di seluruh Jawa Barat.

Semakin dekatnya waktu pelaksanaan Pekan Olahraga Nasional di Jawa Barat membuat kebutuhan informasi akan venue dari setiap cabang olahraga yang dipertandingkan juga semakin meningkat. Namun masyarakat masih kesulitan mencari lokasi venue Pekan Olahraga Nasional. Salah satu solusi untuk mengatasi permasalahan tersebut adalah dengan aplikasi berbasis Location Based Service (LBS).

Layanan berbasis lokasi atau Location Based Service (LBS) adalah layanan yang menyediakan informasi mengenai suatu tempat. LBS dapat diakses dengan perangkat selular dan memiliki kemampuan untuk menggunakan posisi geografis dari pengguna. LBS mendapat posisi geografis dari pengguna dengan menggunakan bantuan GPS (Global Positioning System). GPS merupakan sistem untuk menentukan koordinat posisi dan navigasi secara global dengan menggunakan satelit.

Berdasarkan uraian di atas maka akan dikembangkan sebuah aplikasi berbasis informasi lokasi. Aplikasi berbasis client server, website sebagai server dan Android sebagai client, aplikasi ini akan menyediakan informasi mengenai venue PON XIX Jawa Barat 2016. Dan diharapkan informasi ini dapat membantu pengguna dalam menemukan venue dari setiap cabang olahraga (Cabor) yang dipertandingkan.

\section{$1.2 \quad$ Identifikasi Masalah}

Berdasarkan uraian latar belakang di atas, maka identifikasi masalah dalam membangun aplikasi ini adalah :

1. Bagaimana cara membangun aplikasi client server, website sebagai server dan Android sebagai client, yang dapat memberikan informasi venue PON XIX Jawa Barat 2016.

2. Bagaimana cara mengimplementasikan layanan berbasis lokasi yang menggunakan fasilitas Google API khususnya Maps API untuk pemetaan.

\subsection{Ruang Lingkup}

Dalam melaksanakan perencanaan dan pembuatan sistem yang akan dibuat ini, ruang lingkup permasalahan yang dibahas adalah sebagai berikut :

1. Aplikasi pada sisi client ini dibuat hanya untuk sistem operasi Android.

2. Peta yang digunakan merupakan fasilitas dari Google Maps API.

3. Aplikasi ini menggunakan bahasa pemrograman PHP disisi Server dan bahasa pemrograman Android disisi Client serta menggunakan Database Mysql untuk Database Management System nya.

4. Dibagian server terdapat hanya satu hak akses untuk administrator.

5. Aplikasi tidak dapat terhubung dengan server jika koneksi internet terputus.

6. Aplikasi ini tidak menyediakan fitur informasi tiket dan informasi kursi penonton.

7. Aplikasi dibagian client hanya menggunakan bahasa Indonesia.

8. Dibagian server untuk menambah data koordinat masih dengan manual.

\section{LANDASAN TEORI}

\subsection{Konsep Dasar $\quad$ Model Pengembangan Sistem \\ 2.1.1 Sistem}

Sistem adalah sekelompok elemenelemen yang terintegrasi dengan tujuan yang sama untuk mencapai tujuan. Organisasi terdiri dari sejumlah sumberdaya manusia, material, mesin, uang, dan informasi. Sumber daya tersebut bekerja sama menuju tercapainya suatu tujuan tertentu yang ditentukan oleh pemilik atau manajemen. ${ }^{[8]}$

\subsubsection{Data}

Data adalah kenyataan yang menggambarkan adanya suatu kejadian (event), data terdiri dari fakta (fact) dan angka yang secara relatif tidak berarti bagi pemakai. Data dapat berbentuk nilai yang terformat, teks, citra, audio, dan video. ${ }^{[8]}$

1. Teks adalah sederetan huruf, angka, dan simbol-simbol yang kombinasinya tidak tergantung pada masing-masing item secara individual misalnya, artikel, koran, majalah. 
2. Data yang terformat adalah data dengan suatu format tertentu, misalnya data yang menyatakan tanggal atau jam, dan nilai mata uang.

3. Citra (image) adalah data dalam bentuk gambar, citra dapat berupa grafik, foto, hasil ronsten, dan tanda tangan.

4. Audio adalah data dalam bentuk suara misalnya instrument musik, suara orang, suara binatang, detak jantung.

5. Video adalah data dalam bentuk gambar yang bergerak dan dilengkapi dengan suara misalnya, suatu kejadian dan aktivitas-aktivitas dalam bentuk film.

\subsubsection{Informasi}

Informasi (information) adalah data yang diolah menjadi bentuk lebih berguna dan lebih berarti bagi yang menerimanya. Informasi juga disebut data yang diproses atau data yang memiliki arti. Informasi merupakan data yang telah diproses sedemikian rupa sehingga meningkatkan pengetahuan seseorang yang menggunakan. Para pembuat keputusan memahami bahwa informasi menjadi faktor kritis dalam menentukan kesuksesan atau kegagalan dalam suatu bidang. Sistem apapun tanpa ada informasi tidak akan berguna, karena sistem tersebut akan mengalami kemacetan dan akhirnya berhenti. Informasi dapat berupa data mentah, data tersusun, kapasitas sebuah saluran informasi, dan sebagainya. ${ }^{[8]}$ Hubungan antara data informasi digambarkan sebagai berikut :

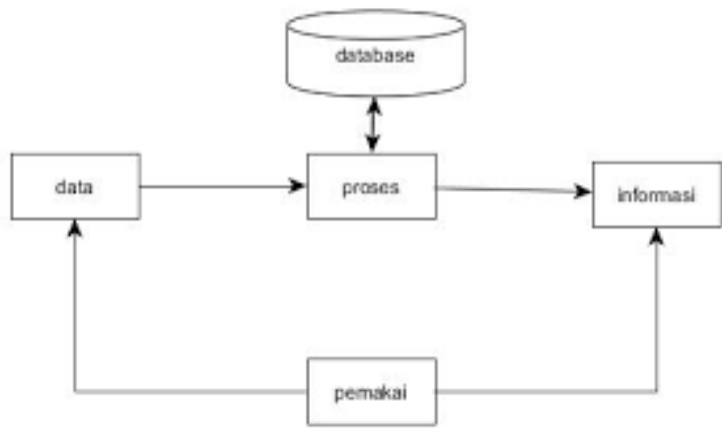

Gambar 1 : Pemrosesan Data Menjadi Informasi

\subsubsection{Sistem Informasi}

Sistem informasi (information system) merupakan kombinasi teratur dari orang-orang, perangkat keras (hardware), perangkat lunak (software), jaringan komunikasi, dan sumber daya data organisasi. Sistem informasi adalah suatu sistem di dalam suatu organisasi yang mempertemukan kebutuhan pengolahan data transaksi harian, mendukung operasi, bersifat manajerial dan kegiatan strategi dari suatu organisasi serta menyediakan pihak luar tertentu dengan laporan-laporan yang diperlukan. Sistem informasi juga dapat didefinisikan sebagai suatu sistem yang dibuat oleh manusia yang terdiri dari komponenkomponen dalam organisasi untuk menyajikan informasi. Sistem informasi merupakan sistem pembangkit informasi, kemudian dengan integrasi yang dimiliki antar subsistem, maka sistem informasi akan mampu menyediakan informasi yang berkualitas, tepat, cepat, dan akurat sesuai dengan manajemen yang membutuhkannya. ${ }^{[8]}$

\subsubsection{Model Pengembangan Sistem}

Model air terjun (waterfall) sering juga disebut model sekuensial linier (sequential linear) atau alur hidup klasik (classic life). Model air terjun menyediakan pendekatan alur hidup perangkat lunak secara sekuensial atau terurut dimulai dari analisis, desain, pengkodean, pengujian dan tahap pendukung (support). ${ }^{[6]}$

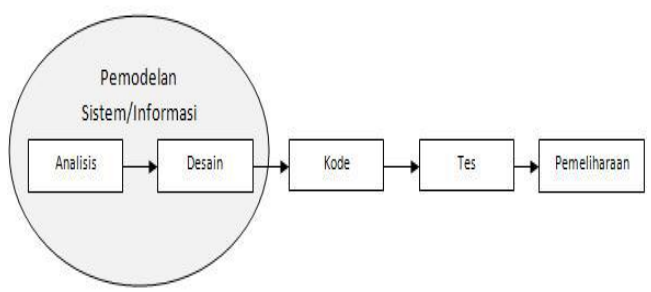

Gambar 2 : Model Waterfall

\subsection{Konsep Dasar Pemrograman \\ 2.2.1 Sistem Operasi Android}

1. Pengenalan Android

Android adalah Sistem operasi untuk handphone yang berbasis linux. Android menyediakan platform terbuka bagi para pengembang buat menciptakan aplikasi mereka sendiri untuk digunakan oleh bermacam peranti bergerak. Awalnya, google Inc. membeli Android Inc. pendatang baru yang membuat peranti lunak untuk handphone kemudian untuk mengembangkan Android, dibentuklah Open Handset Alliance, konsorsium dari 34 perusahaan peranti keras, peranti lunak, dan telekomunikasi. Pada saat perilisan perdana Android, 5 November 2007, 
Android bersama Open Handset Allliance menyatakan mendukung pengembang standar terbuka pada perangkat seluler. Di lain pihak, Google merilis kode-kode android di bawah lisensi Apache, sebuah lisensi perangkat software dan standar terbuka perangkat seluler. Di dunia ini terdapat dua jenis distributor sistem operasi Android. Pertama yang mendapat dukungan penuh dari Google atau Google Mail Service (GMS), dan kedua adalah yang benar-benar bebas distribusinya tanpa dukungan langsung Google atau dikenal sebagai Open Handset Distribution (OHD).

Android merupakan sistem operasi yang berkembang pesat, namun tidak menjadikannya sistem operasi yang sempurna ada beberapa kekurangan dari sistem operasi Android diantaranya Android terkesan rumit, kerena mempunyai banyak sekali widget maupun aplikasi dengan banyak pengaturan sehingga pengguna harus banyak belajar mengenai Android, selain itu Android yang merupakan sistem operasi terbuka sehingga pengguna dapat memasang aplikasi di luar tool aplikasi yang ditawarkan oleh perangkat Android tersebut sehingga sangat rentan terkena ancaman malware atau virus. Tidak semua perangkat Android dapat langsung memperbaharui sistem operasi terbaru, karena produsen smartphone lebih mementingkan produk baru untuk diberi sistem operasi yang terbaru, dibandingkan dengan memberi pemberitahuan tentang update sistem operasi terbaru sehingga membutuhkan waktu lama untuk memperbarui sistem operasi bagi beberapa perangkat. ${ }^{[2]}$

\section{Perkembangan Sistem Operasi Android}

Keunikan dari nama sistem operasi (OS) Android adalah dengan menggunakan nama makanan hidangan penutup (Dessert). Selain itu juga nama-nama sistem operasi Android memiliki huruf awal berurutan sesuai abjad.

a. Android 1.0 Astro Pertama kali dirilis pada 23 Spetember 2008.

b. Android 1.1 Bender,Pertama kali dirilis pada 9 Februari 2009.

c. Android 1.5 Cupcake, Pertama kali dirilis pada 30 April 2009

d. Android 1.6 Donut, Dirilis pertama kali pada 15 September 2009. Terdapat peningkatan pada fitur pencarian dan UI yang lebih user friendly. Pada versi ini terdapat beberapa keunggulan fitur diantaranya ${ }^{[10]}$ :

1. Quick Search Box (kotak pencarian cepat)

2. Screen Size Diversity (ukuran keragaman layar)

3. Android Market

e. Android 2.0/2.1 EclairDirilis pertama kali pada 9 Desember 2009. Pada versi ini terdapat beberapa keunggulan fitur diantaranya ${ }^{[10]}$ :

1. Google Maps Navigation

2. Home Screen Customization

3. Speech To Text

f. Android 2.2 Froyo (Froze Yoghurt)

Dirilis pertamakali pada 20 Mei 2010 pada smartphone Google Nexus One. Pada versi ini terdapat beberapa keunggulan fitur diantaranya ${ }^{[10]}$ :

1. Voice Actions

2. Portable Hotspot

3. Performance

g. Android 2.3 Gingerbread

Pertama kali diperkenalkan pada 6

Desember 2010. Pada versi ini terdapat beberapa keunggulan fitur diantaranya ${ }^{[10]}$ :

1. Gaming APIs

2. NFC (Near Field Communication (NFC)

3. Battery Management

h. Android 3.0/3.1 Honeycomb

Pertama kali diperkenalkan pada 22

Februari 2011. Beberapa keunggulan fitur pada versi ini adalah ${ }^{[10]}$ :

1. Friendly Design

2. System Bar

3. Quick Setting

i. Android 4.0 ICS (Ice Cream Sandwidch)

Pertama kali dirilis pada 19 Oktober

2011. Pada versi ini terdapat beberapa keunggulan fitur diantaranya ${ }^{[10]}$ :

1. Custom Home Screen

2. Data Usage Control

3. Android Beam

j. $\quad$ Android versi 4.1/4.3 (Jelly Bean)

Android Jelly Bean yang diluncurkan pada tanggal 27 juni 2012 Beberapa keunggulan dari Android versi Jelly Bean ini adalah sebagai berikut ${ }^{[10]}$ :

1. Google Now

2. Actionable Notifications

3. Account Switching

k. Android versi 4.4/4.4.4 (Kitkat) 
Dirilis pertama pada tanggal 31 bulan Oktober tahun 2013 Pada versi ini terdapat keunggulan fitur diantaranya ${ }^{[10]}$ :

1. Voice: Ok Google

2. Immersive Design

3. Smarter Dialer

1. Android versi 5.0 (Lollipop)

Dirilis pertama pada tahun 2014 dikenal dengan nama Android Lollipop. Pada versi ini terdapat keunggulan fitur diantaranya ${ }^{[10]}$.

1. Desain material

2. Multiscreen

3. Notifications

m. Android versi 6.0 (Marsmallow)

Dirilis pada 28 Mei tahun 2015, pada versi ini terdapat keunggulan fitur diantaranya ${ }^{[10]}$ :

1. Permissions (izin)

2. Now On Tap (tekan sekarang)

3. Battery

\section{Arsitektur Android}

Secara garis besar arsitektur Android dapat dijelaskan sebagai berikut:[5]

a. Applications dan Widgets

Application dan Widgets adalah layer dimana berhubungan dengan aplikasi saja, dimana biasanya download aplikasi dijalankan kemudian dilakukan instalasi dan jalankan aplikasi tersebut.

b. Applications Frameworks

Application Frameworks adalah layer di mana para pembuat aplikasi melakukan pengembangan/pembuatan aplikasi yang akan dijalankan di sistem operasi Android, karena pada layer inilah aplikasi dapat dirancang dan dibuat, seperti kontak providers yang berupa sms dan panggilan telepon.

c. Libraries

Libraries adalah layer dimana fitur-fitur Android berada, biasanya para pembuat aplikasi mengakses libraries untuk menjalankan aplikasinya.

d. Android Run Time

Layer yang membuat aplikasi Android dapat dijalankan dimana dalam prosesnya menggunakan implementasi linux.

e. Linux Kernel

Linux Kernel adalah layer dimana inti dari operating system dari Android itu sendiri, berisi file-file sistem yang mengatur system processing, memory, resource, drivers, dan sistem-sistem operasi Android lainnya

\subsubsection{JAVA}

Java merupakan bahasa pemrograman berorientasi objek yang memiliki kemampuan multiplatform, dapat dijalankan sekaligus di berbagai sistem operasi, sesuai dengan mottonya "write once run everywhere" disamping itu, software berbasis java juga dapat dijalankan di mesin apapun tanpa harus diubah kode programnya. ${ }^{[3]}$

\subsubsection{Apache Webserver}

Web server merupakan server internet yang mampu melayani koneksi mengirim data dalam protocol HTTP. Web server merupakan hal yang terpenting dari server di internet dibandingkan server lainnya seperti e-mail server, ftp server ataupun news server. Hal ini disebabkan web server telah dirancang untuk dapat melayani beragam jenis data, dari text sampai grafis 3 dimensi. Kemampuan ini telah menyebabkan berbagai institusi seperti universitas maupun perusahaan dapat menerima kehadirannya dan juga sekaligus menggunakannya sebagai sarana di internet. ${ }^{[3]}$

\subsubsection{PHP}

PHP (akronim dari PHP: Hypertext Preprocessor) adalah bahasa pemrograman yang berfungsi untuk membuat website dinamis maupun aplikasi web. Berbeda dengan HTML yang hanya bisa menampilkan konten statis, PHP bisa berinteraksi dengan database, file dan folder, sehingga membuat PHP bisa menampilkan konten yang dinamis dari sebuah website. Blog, Toko Online, CMS, Forum, dan Website Social Networking adalah contoh aplikasi web yang bisa dibuat oleh PHP. PHP ditulis (diciptakan) oleh Rasmus Lerdorf, seorang software engineer asal Greenland sekitar tahun 1995. Pada awalnya PHP digunakan Rasmus hanya sebagai pencatat jumlah pengunjung pada website pribadi beliau. Karena itu bahasa tersebut dinamakan Personal Home Page (PHP) Tools. Tetapi karena perkembangan nya yang cukup disukai oleh komunitas nya, maka beliau pun merilis bahasa PHP tersebut ke publik dengan lisensi open-source. ${ }^{[1]}$

\subsubsection{MySQL}

MySQL adalah multiuser database yang menggunakan bahasa Strucktured Query Language (SQL). MySQL dalam operasi 
client-server melibatkan server daemon MySQL disisi SQL adalah bahasa standar yang digunakan untuk mengakses database server.MySQL merupakan software database yang paling populer di lingkungan Linux, kepopuleran ini karena ditunjang performa query dari databasenya yang saat ini bisa dikatakan paling cepat dan jarang bermasalah. MySQL ini juga sudah dapat berjalan pada lingkungan Windows. ${ }^{[1]}$

\subsubsection{Location Based Service}

1. Pengenalan Location Based Service Location Based Service (LBS) merupakan sebuah layanan informasi yang dapat diakses dengan perangkat bergerak melalui jaringan dan mampu menampilkan posisi secara geografis keberadaan perangkat bergerak tersebut. ${ }^{[2]}$ LBS dapat berfungsi sebagai layanan untuk mendefinisikan lokasi dari seseorang atau suatu objek tertentu, dan juuga dapat beraksi aktif terhadap perubahan entitas posisi sehingga mampu mendeteksi letak objek dan memberikan layanan sesuai dengan letak objek yang telah diketahui tersebut. Pada teknologi LBS berbasis seluler, penentuan posisi sebuah peralatan komunikasi bergerak ditentukan berdasarkan posisi relative peralatan tersebut terhadap lokasi BTS (Base Tranceiver Station). LBS merupakan layanan IP-nirkabel yang menggunakan informasi geografi untuk memberikan layanan kepada pengguna perangkat mobile.

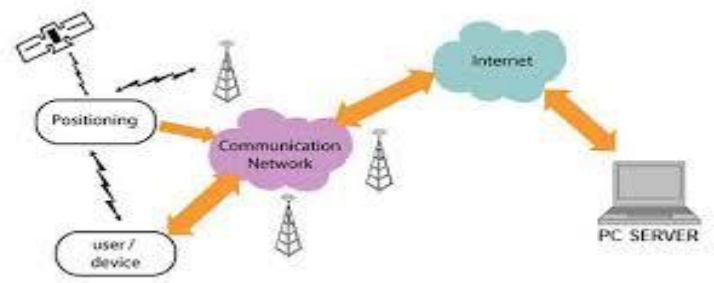

Gambar 3 : Skema Location Based Service

2. Unsur Utama Location Based Service

a. Location Manager (API Maps): menyediakan perangkat bagi sumber atu source untuk LBS, menyediakan fasilitas untuk menampilkan atau memanipulasi peta. $^{[2]}$

b. Location Providers (API Location): menyediakan teknologi pencarian lokasi yang digunakan oleh perangkat. API Location berhubungan dengan data GPS (Global Positioning System) dan data lokasi real time. ${ }^{[2]}$

3. Komponen Location Based Service

Terdapat lima komponen pendukung utama dalam teknologi Layanan Berbasis Lokasi, antara lain: ${ }^{[2]}$

a. Piranti Mobile, adalah salah satu komponen penting dalam LBS. piranti ini berfungsi sebagai alat bantu (tool) bagi pengguna untuk meminta informasi. Hasil dari informasi yang diminta dapat berupa teks, suara, gambar dan lain sebagainya. Piranti mobile yang dapat digunakan bias berupa PDA, smartphone, laptop. Selain itu piranti mobile dapat juga berfungsi sebagai alat navigasi di kendaraan seperti halnya alat navigasi berbasis GPS.

b. Jaringan Komunikasi, komponen ini berfungsi sebagai jalur penghubung yang dapat mengirimkan data-data yang dikirim oleh pengguna dari piranti mobile-nya untuk kemudian dikirimkan ke penyedia layanan dan kemudian hasil permintaan tersebut dikirimkan kembali oleh penyedia layanan kepada pengguna.

c. Komponen Positioning (petunjuk posisi/lokasi), setiap layanan yang diberikan oleh penyedia layanan biasanya akan berdasarkan pada posisi pengguna yang meminta layanan tersebut. Oleh karena itu diperlukan komponen yang berfungsi sebagai pengolah/pemroses yang akan menentukan posisi pengguna layanan saat itu. Posisi pengguna tersebut bias didapatkan melalui jaringan komunikasi mobile atau juga menggunakan Global Positioning System (GPS).

d. Penyedia layanan dan aplikasi, merupakan komponen LBS yang memberikan berbagai macam layanan yang bisa digunakan oleh pengguna. Sebagai contoh ketika pengguna meminta layanan agar bisa tahu posisinya saat itu, maka aplikasi dan penyedia layanan langsung memproses permintaan tersebut, mulai dari menghitung dan menentukan posisi 
pengguna, menentukan rute jalan, mencari data, dan lain-lain.

e. Penyedia data dan konten, penyedia layanan tidak selalu menyimpan seluruh data dan informasi yang diolahnya. Karena bisa jadi berbagai macam data dan informasi yang diolah tersebut berasal dari pengembang/pihak ketiga yang memang memiliki otoritas untuk menyimpannya. Sebagai contoh basis data geografis dan lokasi bisa saja berasal dari badan-badan milik pemerintah atau juga data-data perusahaan/bisnis/industri.

\subsubsection{Google Maps}

Google Maps adalah sebuah jasa peta globe virtual gratis dan online disediakan oleh Google dapat ditemukan di http://maps.google.com. Google Map menawarkan peta yang dapat diseret dan gambar satelit untuk seluruh dunia dan juga menawarkan perencana rute dan pencari letak $^{[4]}$

Google Map API adalah aplikasi interface yang dapat diakses lewat javascript. Untuk dapat mengakses Google Maps, user harus melakukan pendaftaran API Key terlebih dahulu.

API Key adalah sederetan kode sebagai izin untuk menampilkan Google Map pada sebuah halaman web.

1. Koordinat

Koordinat adalah data yang dapat digunakan untuk menentukan lokasi pada peta atau citra satelit yang ditampilkan pada google maps, menentukan jarak dari suatu tempat ke tempat lain, menentukan luas suatu area, dan menentukan zona waktu. ${ }^{[1]}$

a. Latitude (Garis Lintang)

Latitude adalah garis khayal yang digunakan untuk menentukan lokasi di bumi terhadap garis khatulistiwa (utara dan selatan).

b. Longitude (Garis Bujur)

Longitude menggambarkan lokasi sebuah tempat di timur atau barat bumi dari sebuah garis utara-selatan yang disebut Meridian Utama

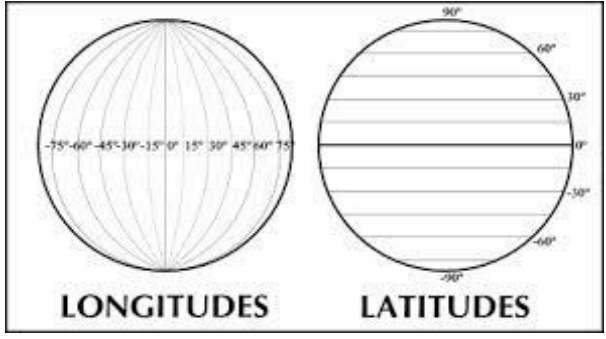

Gambar 4 : Latitude Longitude

\section{Marker}

Marker adalah simbol yang menandakan suatu lokasi suatu tempat pada peta yang ditampilkan google maps.

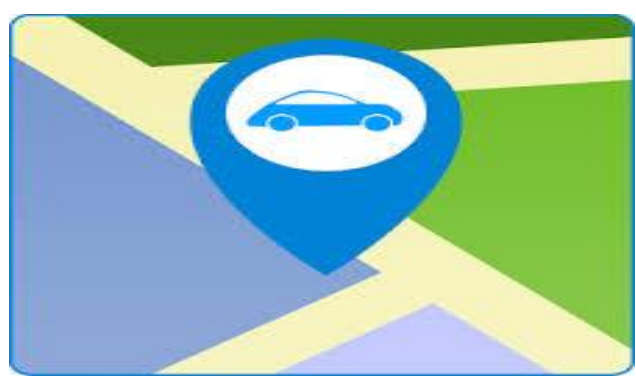

Gambar 5 : Marker

\section{RANCANGAN SISTEM}

\subsection{Analisa Kebutuhan Software}

Software atau aplikasi yang dibutuhkan dalam pembangunan aplikasi informasi lokasi venue PON XIX Jabar 2016 ini terdiri dari XAMPP, dimana aplikasi XAMPP berperan sebagai server local , didalam XAMPP terdapat beberapa aplikasi yang dibutuhkan untuk mengembangkan aplikasi berbasis web, desktop maupun mobile yaitu seperti Apache, MySQL, FileZilla dan Mercury.

XAMPP digunakan untuk menguji program aplikasi disisi localhost yang masih tersimpan dipenyimpanan local Komputer. kemudian setelah semua program dan kode berjalan dengan baik, aplikasi akan dipublikasikan, dengan kata lain database MySQL akan disimpan di server pusat, agar semua pengguna bisa mengaksesnya dimana saja dan kapan saja.

Disisi Client untuk membangun aplikasi informasi lokasi venue PON XIX Jawa Barat berbasis mobile, menggunakan software Eclipse sebagai alat bantunya, software Eclipse mendukung bahasa pemrograman Java, karena 
Android menggunakan bahasa pemrograman java maka Eclipse sangat cocok digunakan untuk mengembangkan aplikasi berbasis Android.

\subsection{Desain \\ 3.2.1 UML \\ 1. Use case}

a. Use case Admin

Use Case Diagram menjelaskan fungsi yang dimiiki oleh sistem dari segi fungsionalitas yang dilakukan oleh pengguna sistem. Interaksi yang terdapat dalam aplikasi ini digambarkan dalam bentuk usecase diagram sebagai berikut:

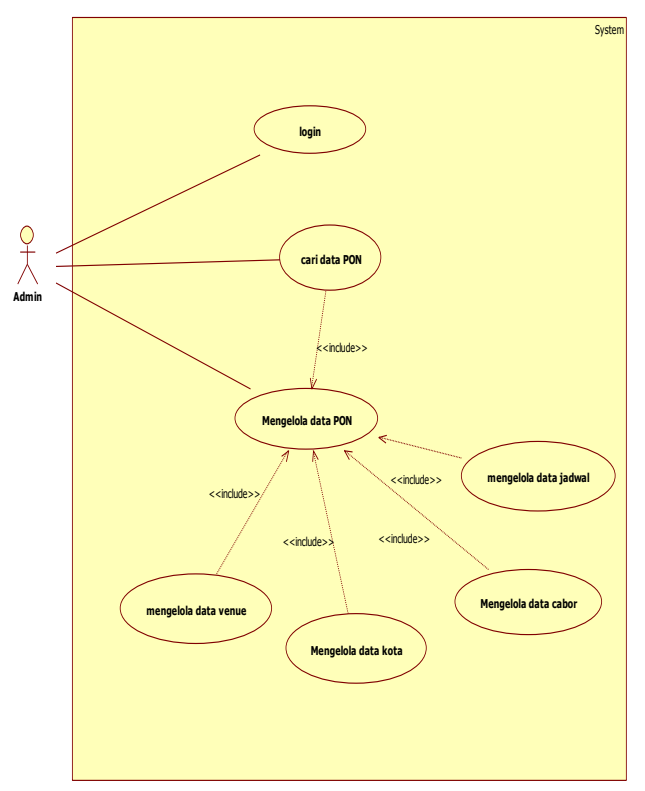

Gambar 6 : Use case Admin

Gambar IV.1 merupakan diagram Use case Admin yang menunjukkan interaksi antara Administrator dengan sistem. Dijelaskan bahwa pada saat memulai aplikasi ini administrator harus login terlebih dahulu. Kemudian administrator dapat memilih menu yang tersedia dan mengelola data tambah, edit, atau hapus dari menu yang dipilih. b. Use case Pengguna

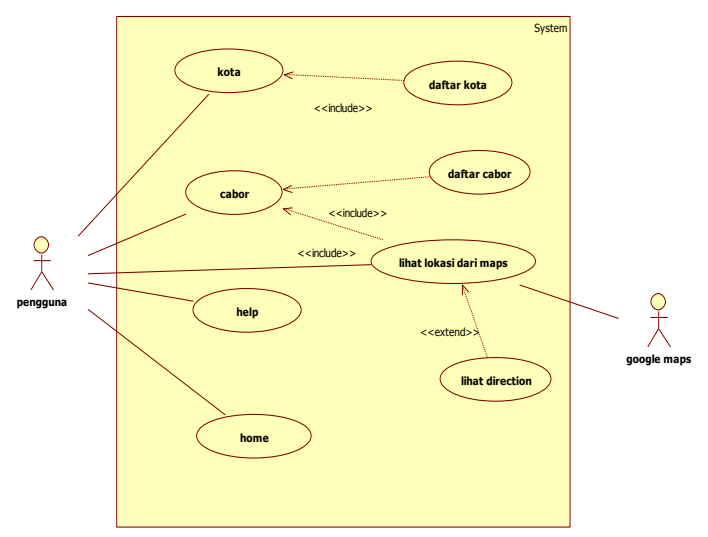

Gambar 7 : Use case Pengguna

Gambar IV.2 merupakan diagram Use case Pengguna yang menunjukkan interaksi antara pengguna dengan sistem. Pada saat memulai aplikasi ini pengguna dapat memilih menu yang tersedia, beranda, kota, cabor, bantuan. Saat memilih menu cabor pengguna mendapat informasi melalui maps.

\section{Relasi Tabel}
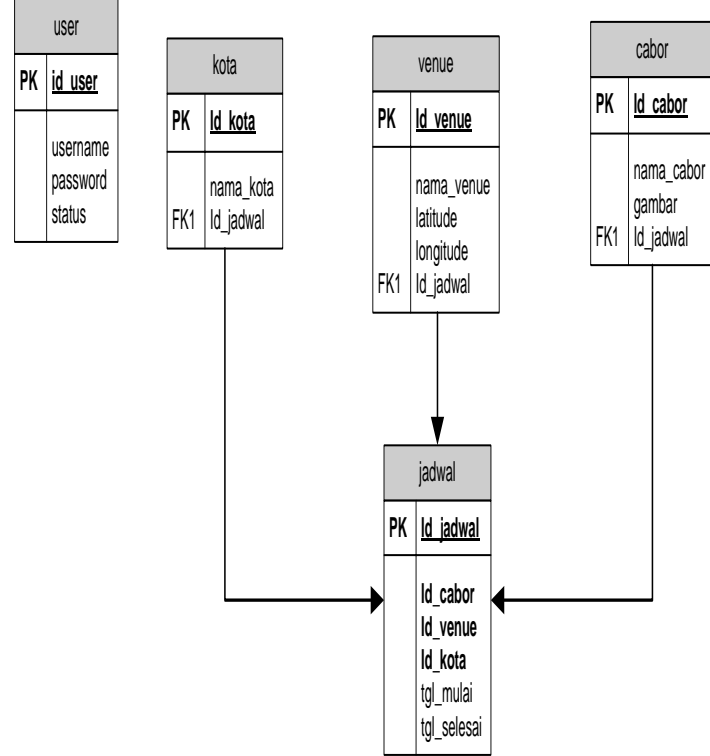

Gambar 8 : Relasi Tabel

\subsubsection{Software Architecture}

Gambaran dari software architecture untuk aplikasi venue PON Jabar adalah seperti gambar dibawah ini. 


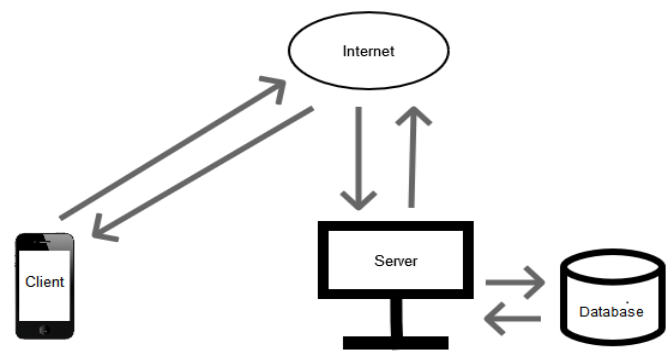

Gambar 9 : Software Architecture

Gambar IV.15 Software Architecture menggambarkan aliran data yang terjadi antara interaksi client kepada server. Tanda panah dari client ke internet ke server menjelaskan bahwa client harus terhubung dengan data internet jika akan meminta data dari server, sedangkan panah dari server ke database menjelaskan bahwa server memiliki hak untuk mengelola database. Untuk tanda panah balik dari server ke internet ke client menjelaskan bahwa server memberi data sesuai dengan request dari clent.

\section{Implementasi}

\subsection{Halaman Login Admin}

Halaman ini muncul ketika program pertama kali dijalankan. Tampilan ini digunakan sebagai Kontrol untuk mengaktifkan halaman yang terdapat pada sistem, administrator harus memasukkan username dan password pada textbox selanjutnya pilih tombol login untuk melanjutkan. Jika username dan Password administrator valid maka halaman pada menu utama akan diaktifkan.

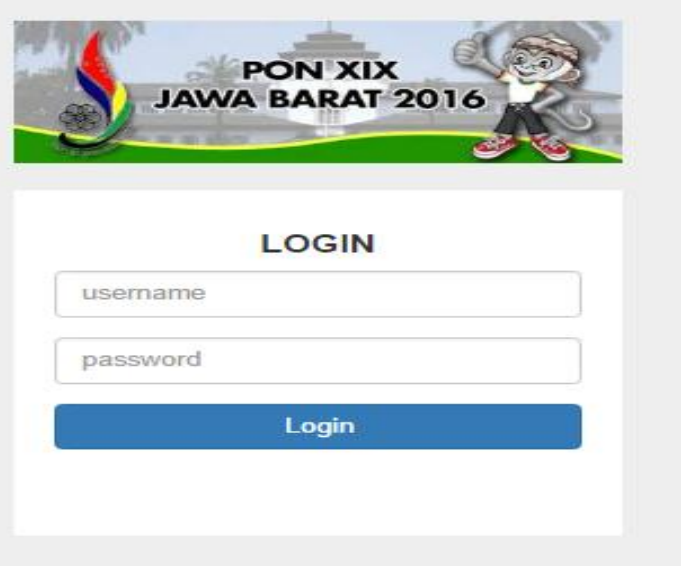

Gambar 10 : Halaman Login Admin

\subsection{Halaman Menu}

Halaman ini merupakan tampilan menu untuk admin. Di halaman tersebut terdapat pilihan menu, yaitu : beranda, cabor, venue, kota, jadwal, dan administrasi. Di bawah pilihan menu ada kolom data yang berisi data dan opsi edit, hapus sesuai dengan data yang dipilih.

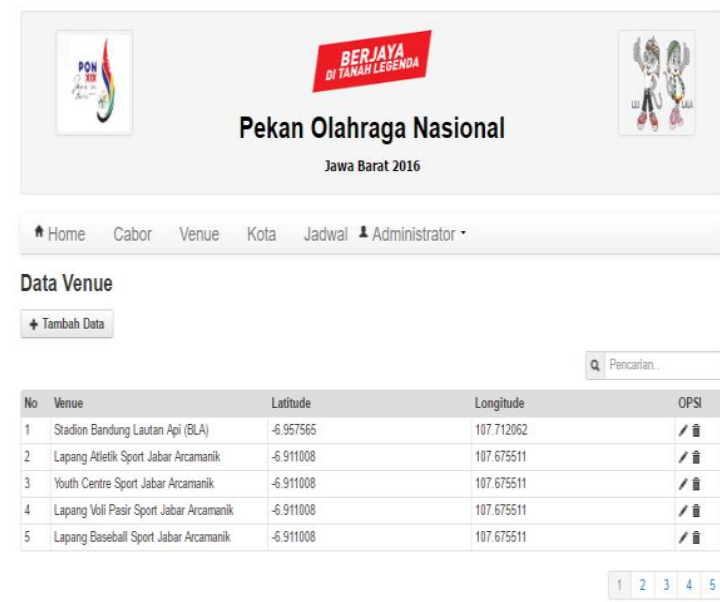

Gambar 11 : Halaman Menu

\subsection{Halaman Tambah Data}

Halaman ini berfungsi untuk tambah data, sesuai dengan menu yang yang dipilih administrator.

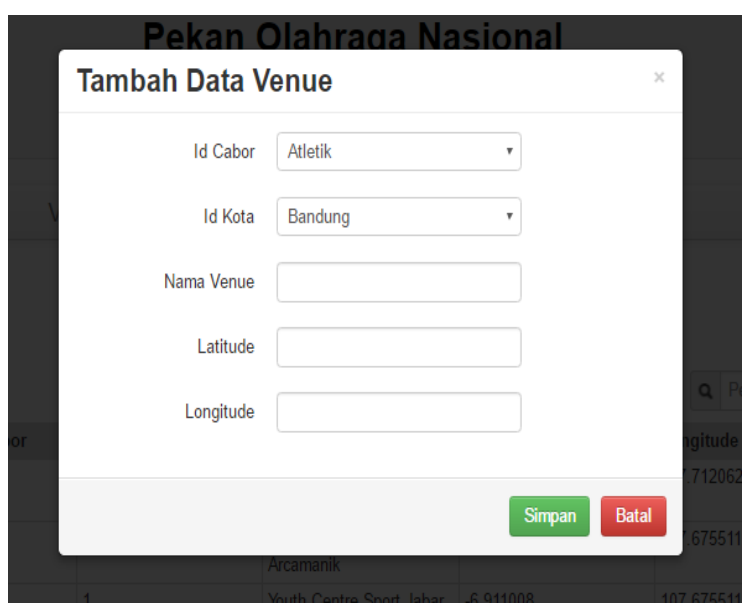

Gambar 12 : Halaman Tambah Data 


\subsection{Halaman Ubah Data}

Halaman ini muncul saat administrator melakukan edit data sesuai dengan data yang dipilih.

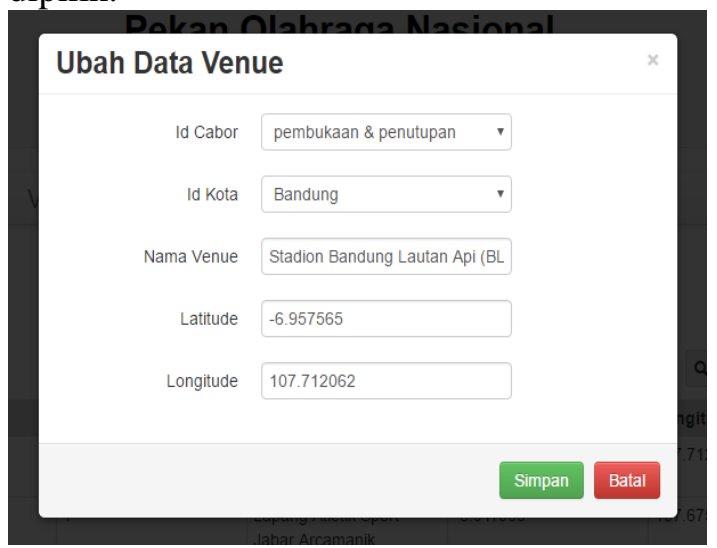

Gambar 13 : Halaman Edit Data

\subsection{Halaman Menu Pengguna}

Halaman ini merupakan tampilan menu untuk pengguna. Di halaman tersebut terdapat pilihan menu, yaitu : beranda, kota, cabor, bantuan.

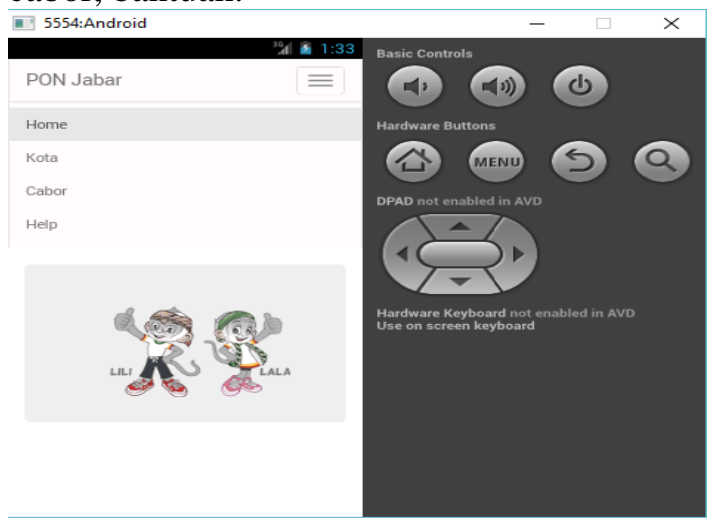

Gambar 14 : Halaman Menu Pengguna

\subsection{Halaman Kota Pengguna}

Halaman ini muncul saat pengguna memilih menu kota. Terdapat combobox untuk menampilkan data list kota. 


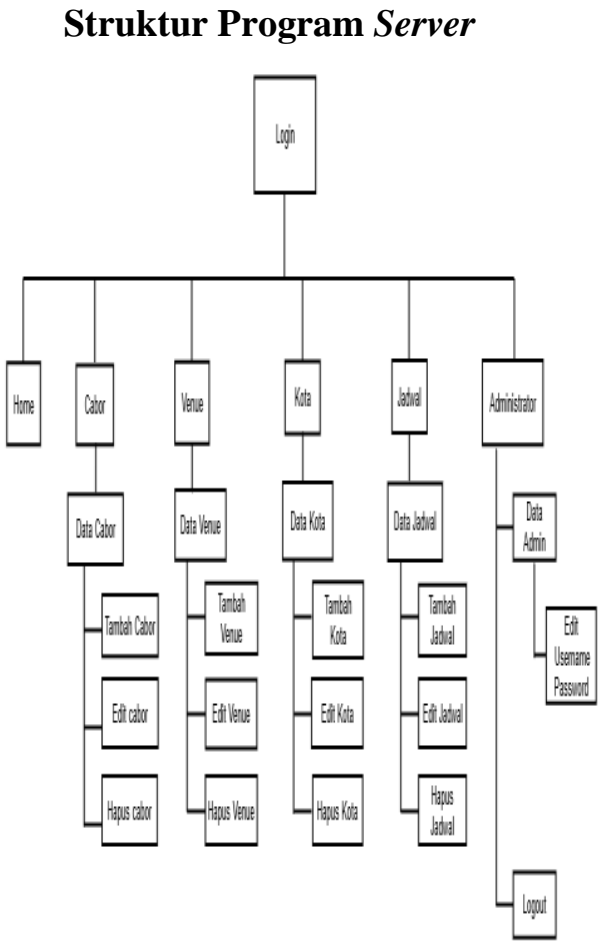

Gambar 17 : Struktur Program Server

\subsection{Struktur Program Client}

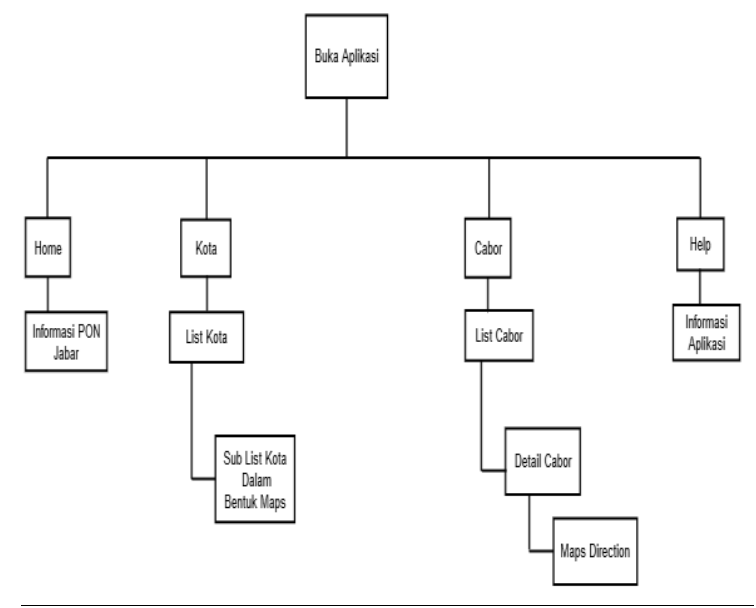

Gambar 18: Struktur Program Client

\section{KESIMPULAN DAN SARAN}

\subsection{Kesimpulan}

Dari hasil pembahasan tentang

Pembangunan Aplikasi Informasi Lokasi Venue PON XIX Jawa Barat Berbasis Android, maka diambil kesimpulan :

1. Aplikasi ini dapat membantu pengguna untuk mendapatkan informasi kota dan venue PON Jawa Barat.
2. Aplikasi ini dapat membantu pengguna dalam menunjukan arah dari lokasi yang ada.

3. Aplikasi harus selalu berjalan dengan koneksi internet untuk mengakses informasi.

4. Kecepatan untuk mendapatkan informasi bergantung pada kecepatan akses internet.

\subsection{Saran}

Agar aplikasi ini dapat lebih optimal dan berjalan sesuai dengan yang diharapkan . ada beberapa saran yang mungkin dapat dipertumbangkan yaitu:

1. Menambahkan fitur mode travel saat pemilihan rute.

2. Adanya fitur informasi tiket dan bangku penonton.

3. Adanya fitur informasi hasil pertandingan.

4. Adanya fitur informasi perolehan medali.

5. Menambah fitur promosi lokasi wisata di setiap kota penyelenggara PON

\section{DAFTAR PUSTAKA}

[1] Andi Wirawan, Joko dan Mochamad. 2008, Amazing Nw Website with PHP, Ajax dan MySQL. Yogyakarta ;Andy

[2] Bahtiar, Nurdin., Helmie Arif Wibawa., Sukmawati Nur Endah., dan Sutikno. 2012. Sistem Informasi dan Rekayasa Perangkat Lunak. Yogyakarta : Graha Ilmu.

[3] H, Nazruddin Safaat. 2012. Pemrogramana Aplikasi Mobile Smartphone dan Tablet PC Berbasis Android. Bandung; Informatika Bandung

[4] Lengkong, Hendra Nugraha. 2015. Perancangan Penunjuk Rute Pada Kendaraan Pribadi Menggunakan Aplikasi Mobile GIS berbasis Android yang Terintegrasi pada Google Maps.Diambil dari : http://ejournal.unsrat.ac.id/index.php/elekdank om/article/download/6817/6341

(Jumat 25 Maret 2016)

[5] Murtiyawati., dan Gleen Lauren. Rancang Bangun Aplikasi Pembelajaran Budaya 
Indonesia Untuk anak Sekolah Dasar Berbasis Android. Volume 12 Nomor: 2, Desember 2013 ISSN :412-9434. Diambil dari http://murtiwiyat.staff.gunadarma.ac.id/publica tions/files/2058/jurnal+andro.id.pdf (Jumat 25 Maret 2016)

[6] Shalahudin, M., dan Rosa A.S.2013. Rekayasa Perangkat Lunak Terstruktur dan Berorientasi Objek. Bandung: Informatika

[7] Widodo, Prabowo Pudjo., dan Heriawati. 2012. Menggunakan UML.Bandung: Informatika.

[8]Yakub.2012. Pengantar Sistem Informasi. Yogyakarta ; Graha Ilmu

[9] Witarto, Memahami sistem informasi, Informatika Bandung, 2004 